\title{
Potato spindle tuber viroid Strains of Different Pathogenicity Induces and Suppresses Expression of Common and Unique Genes in Infected Tomato
}

\author{
Asuka Itaya, ${ }^{1}$ Yoshie Matsuda, ${ }^{1}$ Robert A. Gonzales, ${ }^{2}$ Richard S. Nelson, ${ }^{2}$ Biao Ding ${ }^{1}$ \\ ${ }^{1}$ Department of Plant Biology and Plant Biotechnology Center, Ohio State University, Columbus, U.S.A.; ${ }^{2}$ Plant Biology \\ Division, Samuel Roberts Noble Foundation, Ardmore, OK, U.S.A.
}

Submitted 4 April 2002. Accepted 1 July 2002.

\begin{abstract}
Viroids are the smallest plant pathogens. These RNAs do not encode proteins and are not encapsidated, and yet they can replicate autonomously, move systemically, and cause diseases in infected plants. Notably, strains of a viroid with subtle differences in nucleotide sequences can cause dramatically different symptoms in infected plants. These features make viroids unique probes to investigate the role of a pathogenic RNA genome in triggering host responses. We conducted a comprehensive analysis of the differential gene expression patterns of tomato plants at various stages of infection by a mild and severe strain of Potato spindle tuber viroid (PSTVd). We also compared tomato gene expression altered by the PSTVd strains with that altered by Tobacco mosaic virus (TMV). Our analyses revealed that the two PSTVd strains altered expression of both common and unique tomato genes. These genes encode products involved in defense/stress response, cell wall structure, chloroplast function, protein metabolism, and other diverse functions. Five genes have unknown functions. Four genes are novel. The expression of some but not all of these genes was also altered by TMV infection. Our results indicate that viroids, although structurally simple, can trigger complex host responses. Further characterization of viroid-altered gene expression in a host plant should help understand viroid pathogenicity and, potentially, the mechanisms of RNA-mediated regulation of plant gene expression.
\end{abstract}

Additional keyword: macroarray.

Viroids are single-stranded and covalently closed circular RNAs. They are the smallest plant pathogens known to date. They infect plants including some economically important crops (Diener 2001; Garnsey and Randles 1987). The viroid RNA genomes do not encode proteins and are not encapsidated (Diener 2001; Flores et al. 1997). Nevertheless, viroids can replicate autonomously, move systemically within an infected plant, and cause diseases. The viroid genome must interact directly with host-encoded factors to accomplish these functions. Therefore, viroid infection provides a unique system to study how a host responds to infection by a pathogenic RNA. Viroids have additional advantages for studying host-pathogen interactions. Secondary structures of many viroids have been well

Corresponding author: B. Ding: Department of Plant Biology and Plant Biotechnology, 207 Rightmire Hall, Ohio State University, 1060 Carmack Road, Columbus, OH 43210; Telephone: (614) 247-6077; Fax: (614) 292-5379; E-mail: ding.35@osu.edu. characterized, and there is ample information about how viroid sequence or structural variations are associated with different degrees of pathogenicity (Gruner et al. 1995; Hammond 1992; Hammond and Owens 1987; Hu et al. 1997; Loss et al. 1991; Owens et al. 1986, 1995, 1996; Qu et al. 1993; Schnölzer et al. 1985).

Morphological and cytological changes associated with viroid infection have been well documented (Semancik and Conejero-Tomas 1987). Typical symptoms include stunting, leaf epinasty, and chlorosis. At the cellular level, the most visible symptom is distortion of cell walls and of the plasma membrane (Momma and Takahashi 1982; Paliwal and Singh 1981; Semancik and Vanderwoude 1976; Wahn et al. 1980), chloroplasts (Da Graça and Martin 1981; Hari 1980; Lawson and Hearon 1971; Momma and Takahashi 1982), and mitochondria (Paliwal and Singh 1981).

The molecular mechanisms of viroid pathogenicity, as well as host responses, are poorly understood. Viroid infection causes accumulation of pathogenesis-related (PR) proteins (Gadea et al. 1996; Granell et al. 1987; Lucas et al. 1985; Vera and Conejero 1989). These PR proteins include hydrolytic enzymes such as chitinases (García Breijo et al. 1990) and subtilisin-like endoproteases (Jordá et al. 2000; Tornero et al. 1997; Vera and Conejero 1988, 1989), thaumatin-like proteins (Rodrigo et al. 1991, 1993), and a basic protein PR-1b (Camacho-Henriquez and Sänger 1984; Tornero et al. 1994). Potato spindle tuber viroid (PSTVd) infection also increases the expression of protein kinase PKV (Hammond and Zhao 2000). Citrus exocortis viroid infection enhanced phosphorylation of some proteins while decreasing phosphorylation of others in tomato leaves (Vera and Conejero 1990). These studies demonstrate that viroid infection can trigger general host defense responses mobilized against pathogens, including viruses, bacteria, and fungi. Whether a host has specific responses to viroid infection remains to be investigated. A comprehensive analysis of gene expression patterns in viroidinfected plants should further expand our knowledge of host responses to viroid infection. Furthermore, a comparative analysis of host gene expression patterns during viroid and virus infections may enhance understanding of common and unique host responses to different pathogens.

In this study, we investigated gene expression patterns of tomato (Lycopersicon esculentum Mill cv. Rutgers) at various stages of infection by two strains of PSTVd that cause different degrees of symptoms. We employed polymerase chain reaction (PCR)-based cDNA library subtraction to enrich differentially expressed genes (Akopyants et al. 1998; Diatchenko et al. 1996). We constructed macroarrays containing 1,156 clones 
from the subtracted cDNA library to monitor their expression patterns throughout the infection processes (Bernard et al. 1996; Geng et al. 1998; Jordan 1998; Lanfranchi et al. 1996; Piétu et al. 1996). By these means, we identified 47 tomato genes whose expression was induced or enhanced and eight genes whose expression was decreased or suppressed by viroid infection. Among these, four genes are novel (i.e., genes without hits in BLAST search), and five genes are of unknown function. Tobacco mosaic virus (TMV) infection induced or suppressed expression of six of the viroid-modulated genes. We present our results and discuss their biological implications.

\section{RESULTS}

\section{Symptom expression in tomato plants infected by two strains of PSTVd and TMV.}

Two PSTVd strains were used in our experiments, a mild strain (PSTVd ${ }^{\text {Mild }}$ ) and RG1 (PSTVd ${ }^{\mathrm{RG1}}$ ). These strains differ by three nucleotides in the genome and cause mild and most severe symptoms, respectively, on the infected tomato (Owens et al. 1996). We set up growth conditions such that these symptoms were observed in our infection experiments (Fig. 1). PSTVd $^{\text {RG1 }}$-infected tomato started showing symptoms at 10 days postinoculation (dpi), whereas PSTVd ${ }^{\text {Mild }}$-infected tomato started showing symptoms at 17 dpi. Symptoms included stunting and leaf curling. At $25 \mathrm{dpi}$, it was evident that PSTVd ${ }^{\mathrm{RG} 1}$ infection resulted in much more severe symptoms than PSTVd ${ }^{\text {Mild }}$ infection (Fig. 1).

TMV-infected plants started showing symptoms as early as 3 to 5 dpi (data not shown). TMV infection caused mosaic patterns on the leaves and leaf curling. However, the infected plants started recovering from the disease symptoms at approximately 15 to $17 \mathrm{dpi}$ and eventually became symptomless. This recovering phenomenon may be due to RNA silencing against TMV (Covey et al. 1997; Ratcliff et al. 1997). On the other hand, PSTVd can induce but also escape RNA silencing in tomato (Itaya et al. 2001; Papaefthimiou et al. 2001).

\section{Overall pattern of differential gene expression in PSTVd- and TMV-infected tomato.}

To characterize gene expression patterns in PSTVd-infected tomato plants, we performed PCR-based cDNA library subtractions between PSTVd-infected and mock-inoculated tomato libraries to enrich differentially expressed genes (details discussed below). We obtained a collection of 1,156 subtracted partial cDNA clones (100 to $500 \mathrm{bp}$ ). These clones were analyzed by macroarray for expression profiles during viroid infection. An example of macroarray is presented in Figure 2. The ovals and rectangles in the figure highlight a number of induced and suppressed genes, respectively, in PSTVd ${ }^{\mathrm{RG} 1}$-infected plants. Each oval or rectangle covers a duplicate of the same cDNA clone. The duplicate ensured that the expression pattern of a gene could be reproducibly detected.

We should point out that, since our primary interest was host responses to viroid infection, we did not include a TMV-infected tomato cDNA library on the macroarrays for the current analysis. Certain genes induced or suppressed by TMV infection may not, therefore, be represented on our macroarrays. We used mRNA probes from TMV-infected tomato to hybridize to the macroarrays. This would allow us to test whether any of the clones on the macroarrays were altered by TMV infection.

The general expression patterns of these genes are presented in Figure 3. For each scattered graph, the $\mathrm{X}$ axis displays the expression levels of clones in the mock-inoculated plant, and the $\mathrm{Y}$ axis displays the expression levels of clones in the plant infected with PSTVd ${ }^{\mathrm{RG} 1}$, PSTVd ${ }^{\text {Mild }}$, or TMV as indicated. Data points above and below the best-fit line (black) represent induced and suppressed expressions of the clones respectively. The distance between each data point and the best-fit line is indicative of induction- or suppression-fold. The two PSTVd strains induced and suppressed tomato gene expression mostly starting at $17 \mathrm{dpi}$ and reached the maximum at $25 \mathrm{dpi}$, our latest sampling timepoint. In contrast, TMV induced tomato gene expression most strongly at 5 to $10 \mathrm{dpi}$. Among the three treatments (PSTVd ${ }^{\mathrm{RG} 1}$, PSTVd ${ }^{\text {Mild }}$, and TMV infections), the $\mathrm{PSTVd}^{\mathrm{RG} 1}$-infected tomato showed the strongest response (i.e., the largest number of altered genes and the highest extent of altered expression levels) at $25 \mathrm{dpi}$.

\section{PSTVd $^{\text {RG1 }}$, PSTVd ${ }^{\text {Mild }}$, and TMV induced and suppressed common and unique genes.}

Clones with hybridization intensity less than the median of all clones on the macroarray were removed from analysis, because such weak signals may not be reliable. Because of the stringent criteria used for selecting the clones for sequencing and analysis, some differentially expressed genes might have been eliminated from subsequent analysis if they were rare transcripts or if the amount of DNA spotted on the membrane was low.

Clones that showed more than twofold reproducible (for duplicates within a macroarray and between macroarrays after independent hybridization) enhanced or decreased expressions in PSTVd-infected plants as compared with their expression in mock-inoculated plants were sequenced for further analysis.

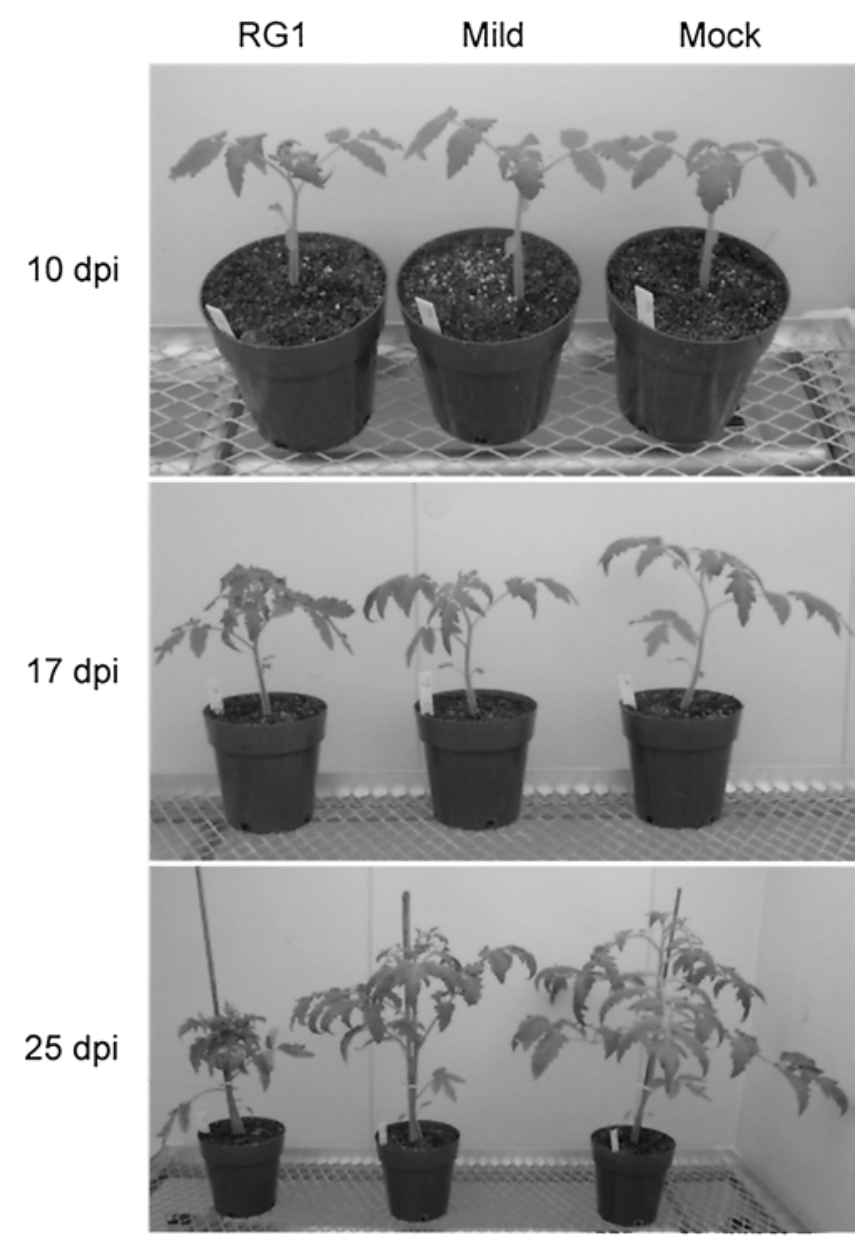

Fig. 1. Symptoms of Potato spindle tuber viroid (PSTVd) infection on Lycopersicon esculentum Mill cv. Rutgers at 10, 17, and 25 days post inoculation. Cotyledons (10-day-old) were inoculated with $80 \mathrm{ng}$ of in vitro transcribed PSTVd RNA. Left: PSTVd ${ }^{\mathrm{RG} 1}$-infected plant. Middle: PSTVd $^{\text {Mild }}$-infected plant. Right: mock-inoculated plant. 
The number of genes with altered expression patterns during each infection is presented in a Venn diagram in Figure 4. These numbers are likely conservative estimates given the stringent criteria used for the selection of genes. PSTVd ${ }^{\mathrm{RG} 1}$ infection altered expression of a total of 52 genes. Among these genes, 27 were altered only by PSTVd ${ }^{\mathrm{RG} 1}$ infection. Of the rest, 10 were also altered by PSTVd ${ }^{\text {Mild }}$ infection, six by TMV infection, and nine by both PSTVd ${ }^{\text {Mild }}$ and TMV infections. In addition, PSTVd ${ }^{\text {Mild }}$ infection altered expression of one unique gene, and TMV infection altered expression of 10 unique genes. Two genes were altered by both PSTVd ${ }^{\text {Mild }}$ and TMV infection but not by PSTVd ${ }^{\mathrm{RG} 1}$ infection. Therefore, PSTVd ${ }^{\mathrm{RG} 1}$, PSTVd $^{\text {Mild }}$, and TMV altered the expression levels of common as well as unique genes.

\section{PSTVd and TMV induced and suppressed genes of diverse functions.}

The temporal expression patterns of differentially expressed genes at successive infection stages are presented in Figure 5. Most PSTVd-induced or suppressed genes show the highest or lowest expression levels, respectively, at 25 dpi. The expression levels of these genes at $25 \mathrm{dpi}$ are summarized in Tables 1 and 2. Please note that the genes are listed in Figure 5 and Tables 1 and 2 in the same order, with GenBank accession numbers given in the tables. Induced genes are putatively involved in defense/stress response, cell wall structure, chloroplast function, protein metabolism, and other diverse functions. Four
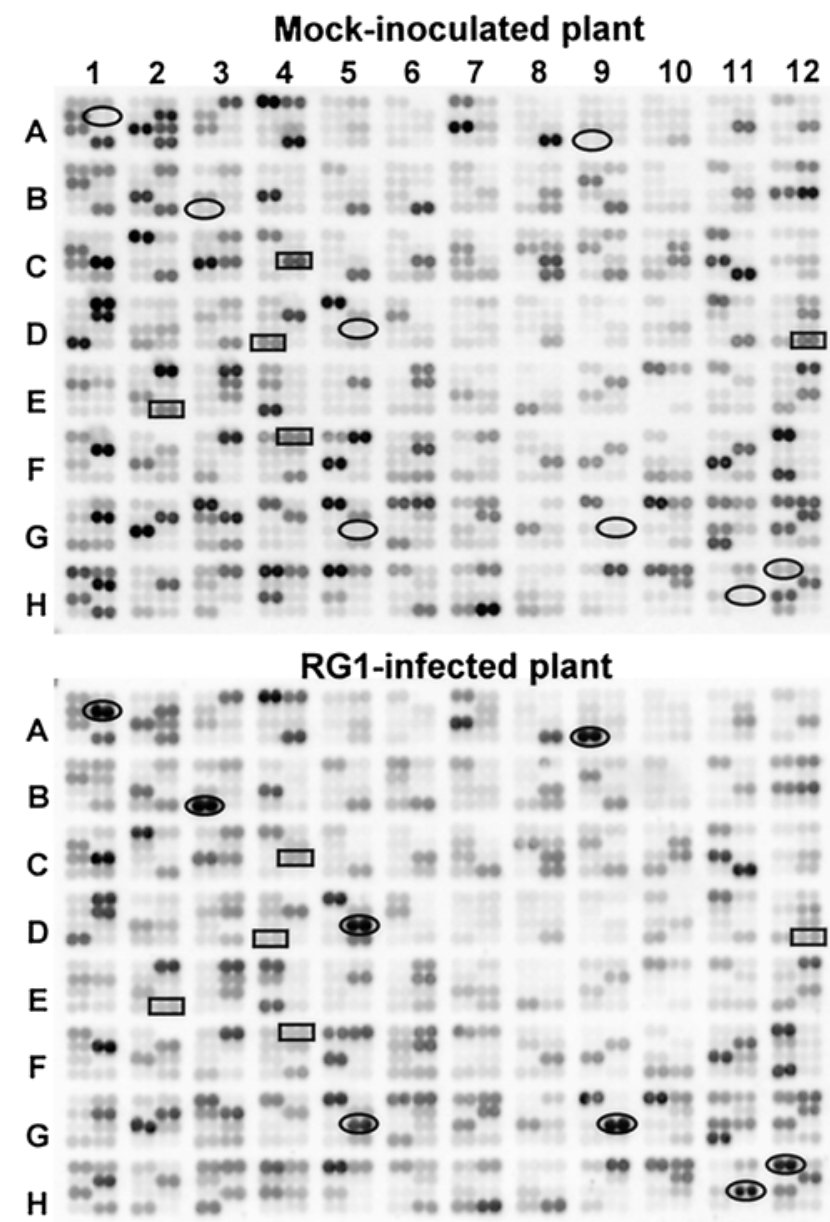

Fig. 2. Example of macroarrays (768 clones from subtracted cDNA library) hybridized with a complex probe prepared from mRNAs of indicated plant samples. Some PSTVd ${ }^{\mathrm{RG} 1}$-induced or enhanced genes are indicated with ovals and suppressed or reduced genes indicated with rectangles. genes have homologs in Arabidopsis with unknown functions. Four genes are novel, with no hits in BLAST search. In general, more genes were induced than suppressed in all infection treatments. Interestingly, these host genes respond to PSTVd infection at a later stage (17 to $25 \mathrm{dpi}$ ), whereas they respond to TMV infection at an early stage (5 to $10 \mathrm{dpi}$ ) (Fig. 5). PSTVd $^{\text {Mild }}$ induces a set of genes in common with PSTVd ${ }^{\mathrm{RG} 1}$, but to a lesser extent (Fig. 5 and Table 1).

Notably, two genes were specifically induced by PSTVd ${ }^{\text {Mild }}$ infection (Fig. 5). These include a gene homologous to the gene encoding mithochondrial 34-kDa porin (GenBank accession number BM956709) and a gene homologous to an unknown gene from Medicago sativa (BM956730). The latter gene was notable, not only because it was specifically induced by PSTVd $^{\text {Mild }}$ infection, but also because it was induced as early as $5 \mathrm{dpi}$, when most genes were not induced or suppressed by PSTVd-infection (Fig. 5). Five genes, encoding PR$1 b$, catalase, cyclophilin, elongation factor, and heat shock protein, were induced by TMV at early stages of infection and by PSTVd $^{\text {RG1 }}$ at late stages of infection (Fig. 5).

Ten genes on macroarrays were induced or suppressed by TMV but not by either strain of PSTVd (Fig. 5). TMV induced expression of genes that encode $\mathrm{Cab} 3 \mathrm{a}$ and phosphoglycerate mutase (GenBank accession numbers BM956691 and BM956648) at $5 \mathrm{dpi}$, phosphoribulokinase, plastidic aldolase, plastidic cystein synthase, proteinase inhibitor, threonine deaminase, and wound-inducible proteinase (accession numbers BM956738, BM956718, BM956694, BM956740, BM956728, and BM956682, respectively) at 10 dpi. TMV, but not PSTVd, suppressed or reduced expression of Rubisco subunit rbc3A at 5 dpi and wound-induced proteinase inhibitor I (accession numbers BM956679 and BM956719, respectively) at $25 \mathrm{dpi}$.

Induction of the $P R-1 b$ gene was the most prominent among all induced genes, to a magnitude of 65 -fold by PSTVd ${ }^{\mathrm{RG} 1}$ and 12 -fold by PSTVd ${ }^{\text {Mild }}$ (Table 1). Induction of this gene by viroid infection was reported previously (Camacho-Henriquez and Sänger 1984; Tornero et al. 1994). One novel gene (BM956717) was suppressed by PSTVd ${ }^{\text {Mild }}$ and TMV, but not by PSTVd ${ }^{\text {RG1 }}$ (Table 2).

A surprising finding was that expression of some genes in a family with similar functions were altered differently by PSTVd or TMV infections. For instance, Cab (Lhcb1-3) was induced by all pathogens, but $C a b 10 b$ and $C a b 9$ were induced only by PSTVd (Fig. 5 and Table 1). Cab 4 was suppressed by both PSTVd ${ }^{\mathrm{RG} 1}$ and PSTVd ${ }^{\text {Mild }}$, whereas Cab 5 was suppressed only by PSTVd $^{\mathrm{RG} 1}$ (Fig. 5 and Table 2 ).

\section{DISCUSSION}

We have investigated the global gene expression patterns of tomato plant upon infection by two strains of PSTVd that cause mild and most severe symptoms. We identified a total of 55 differentially expressed genes in tomato infected by PSTVd but not by TMV. These include four genes of unknown function and three novel genes induced by PSTVd ${ }^{\mathrm{RG} 1}$ and one gene of unknown function induced by PSTVd ${ }^{\text {Mild }}$. We also identified some genes that were induced or suppressed by both PSTVd and TMV and some that were induced or suppressed only by TMV but not by PSTVd. These results are significant in a number of ways. First, they demonstrate that host response to viroid infection can be specific at the level of gene expression. Second, viroid strains with subtle differences in nucleotide sequences and of different pathogenicity can induce or suppress expression of common, as well as unique, host genes. Third, host responses to PSTVd and TMV infections may share some common mechanisms in addition to their unique features. Further characterization of the functions of these genes may cast 
light on their role in normal plant growth and development and in host responses to viroid infection.

The presence in our collection of defense-related genes and genes that were previously reported to be induced by viroid infection indicates the general validity of our approach. However, we did not detect some of the genes that were previously reported to be induced by viroid infection. These include genes encoding an RNA-directed RNA polymerase (RdRp; Schiebel et al. 1998) and a 55-kDa protein kinase viroid (PKV; Hammond and Zhao 2000). Such genes could have escaped our detection due to the criteria (discussed below) we used to select genes for sequencing. We should also point out that the relative expression levels obtained by macroarray analysis may not be accurate, given the potential variation in labeling efficiency of complex probes and in hybridization efficiencies between different experimental sets. Northern hybridization is necessary to verify the data independently. Nevertheless, macroarray provides high throughput analysis of a large number of genes. The general pattern of gene expression revealed by such analysis provides a valuable framework for detailed studies using complementary and functional approaches.

The induced or enhanced expression of genes encoding catalase 1, chitinase, cyclophilin, elongation factor, heat shock protein, and PR-1b by both PSTVd ${ }^{\text {RG1 }}$ and PSTVd ${ }^{\text {Mild }}$ seems to be correlated with the appearance of disease symptoms. The ex- pression level of these genes was higher in PSTVd ${ }^{\mathrm{RG} 1}$-infected plants than in PSTVd ${ }^{\text {Mild }}$-infected plants (Table 1). These genes were also induced by TMV infection (except for chitinase) but at a much earlier stage ( 5 to $10 \mathrm{dpi}$ ) when TMV-infected plants showed disease symptoms. The elevated expression of individual genes or a combination of genes may be partially responsible for the development of disease symptoms. Alternatively, expressions of these genes are the result but not the cause of disease symptoms. Further functional studies are needed to test these possibilities. The time differences for the altered expression of common genes in PSTVd- and TMV-infected plants are probably due to the differing speeds of systemic movement of these pathogens or their differing abilities to trigger host responses.

It is interesting to note a correlation between the altered tomato gene expression profiles and cytological effects of PSTVd infection. Cell walls and chloroplasts are among cellular structures that are often distorted by viroid infection (Semancik and Conejero-Tomas 1987). Superficially, PSTVdinduced or suppressed genes include those that encode components of cell walls and chloroplasts. It will be worthwhile to pursue further whether the altered gene expression can be causally correlated with cytological changes.

PR-1 and $\beta$-1,3-glucanase are typically induced in systemic acquired resistance (SAR) (Clarke et al. 1998; Hunt and Ryals 1996; Thomma et al. 1998). SAR is often induced by avirulent
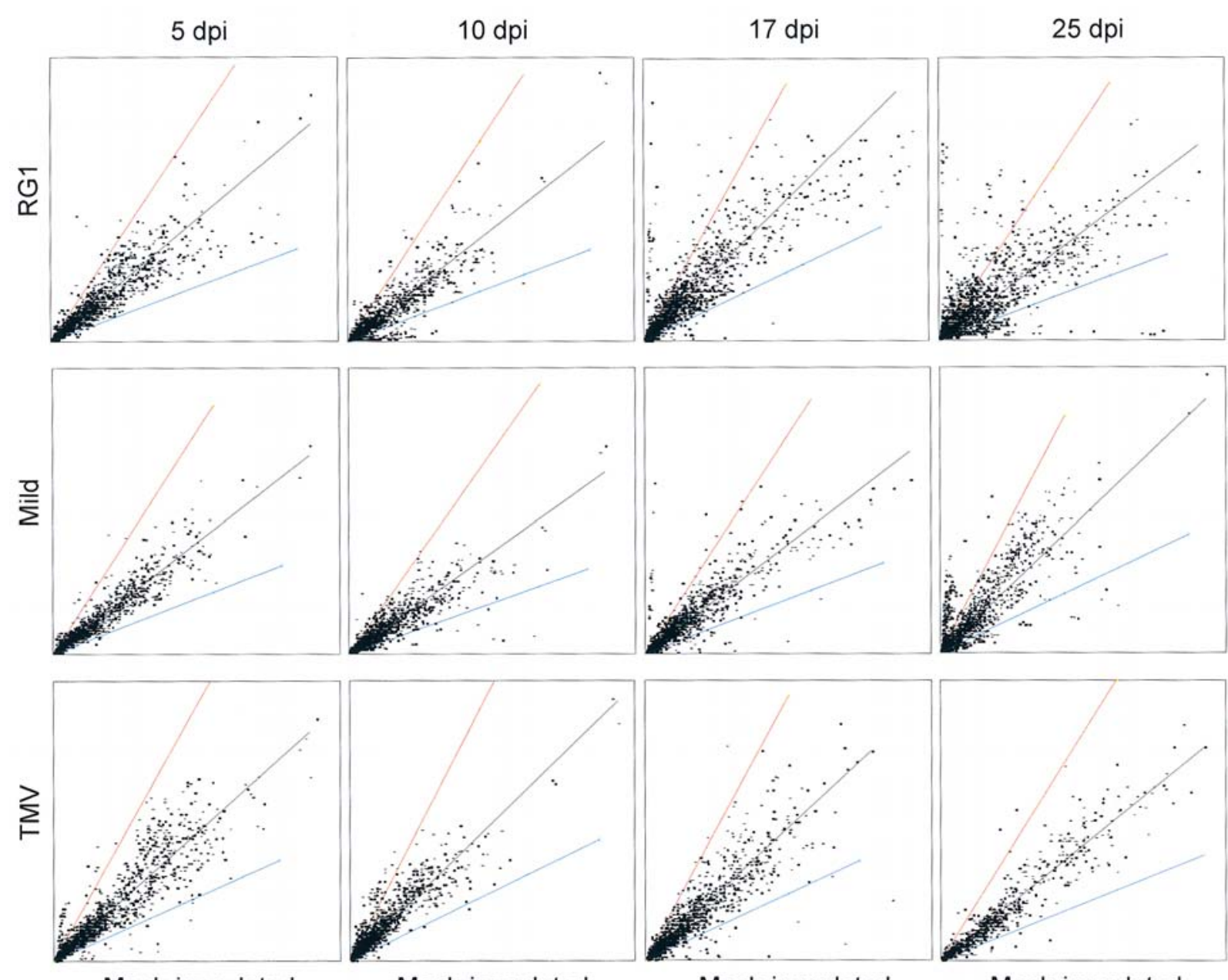

Mock-inoculated

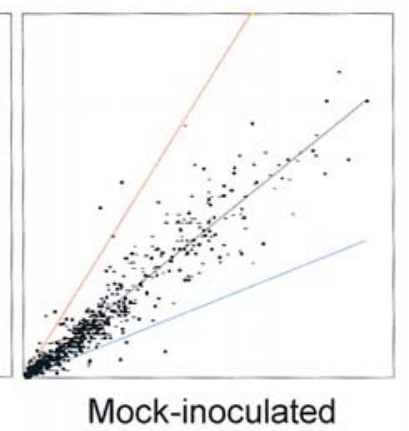

Fig. 3. Expression patterns of 1,156 clones during Potato spindle tuber viroid (PSTVd) and Tobacco mosaic virus (TMV) infection. For each scattered graph, the $\mathrm{X}$ axis displays the expression levels of clones in the mock-inoculated plant, and the $\mathrm{Y}$ axis displays the expression levels of clones in the plant infected with PSTVd ${ }^{\text {RG1 }}$, PSTVd ${ }^{\text {Mild }}$, or TMV as indicated. The days post inoculation (dpi) is indicated at the top of the columns. The diagonal line in the center of each graph represents the best-fit line through the normalized data. The red and blue lines represent twofold induction or repression ratio cutoffs, respectively. 
pathogens carrying an avirulence ( $a v r$ ) gene. The product of an $a v r$ gene is recognized by the product of a resistance $(R)$ gene in plants (gene-for-gene recognition). This recognition causes programmed cell death in the form of hypersensitive response (HR) and induces SAR mediated by salicylic acid (Fritig et al. 1998; Martin 1999). Tomato $R$ genes and corresponding $a v r$ genes are well documented ( $\mathrm{Gu}$ and Martin 1998; Scofield et al. 1996; Tang et al. 1996; Zhou et al. 1997). In the case of viroid infection, however, involvement of $R$ genes is unlikely, since viroids do not encode proteins. Therefore, it will be of great interest to elucidate the PSTVd-activated pathway that is cross-linked with a SAR pathway to activate common downstream genes encoding PR-1 and $\beta$-1, 3-glucanase.

Interestingly, PSTVd-infection induced the expression of some members of the $C a b$ gene family ( $C a b 1, C a b 2, C a b 3,3 a$, 9 , and $10 b$ ) while suppressing the expression of the other members ( $C a b 4$ and $C a b 5$ ). Different members of the $C a b$ gene family are differentially expressed during plant development in soybean (Chang and Walling 1992). Salicylic acid treatment induces $C a b$ gene expression (Schenk et al. 2000), while sugar treatment suppresses it (Herbers et al. 1996). Notably, both salicylic acid and sugar treatment result in induction of PR proteins (Herbers et al. 1996). A crosslink between light signal transduction and PR gene signaling has been speculated (Genoud and Métraux 1999). Our results, together with other reports, suggest potential differences in the function and regulation of different members of the $C a b$ gene family and their relationship to regulation of PR proteins.

Induction of genes encoding elongation factors, ribosomal proteins, ubiquitins, ubiquitin extension proteins, and heat shock proteins by PSTVd suggest the active synthesis and degradation of proteins during viroid infection. A similar phenomenon was also observed during viral (Aranda et al. 1996; Escaler et al. 2000a, 2000b; Havelda and Maule 2000) and fungal (McCafferty and Talbot 1998) infection. The significance of viroid-induced expression of genes involved in protein metabolism remains to be understood.

The mechanisms underlying altered tomato gene expression during PSTVd infection are not clear from the present study. Many stress-related genes induced by PSTVd are likely induced in response to stress conditions. On the other hand, some genes are induced or suppressed by the viroid but not by TMV or only by a specific strain of the viroid. Our data suggest that a viroid can alter the expression patterns of certain plant genes by specific interactions. Some possible mechanisms include: i) interference with mRNA splicing (Diener 1981; Dickson 1981), ii) interference with RNA export out of the nucleus, iii) activation of kinases that phosphorylate host proteins key to gene regulation (Diener et al. 1993; Hiddinga et al. 1988;

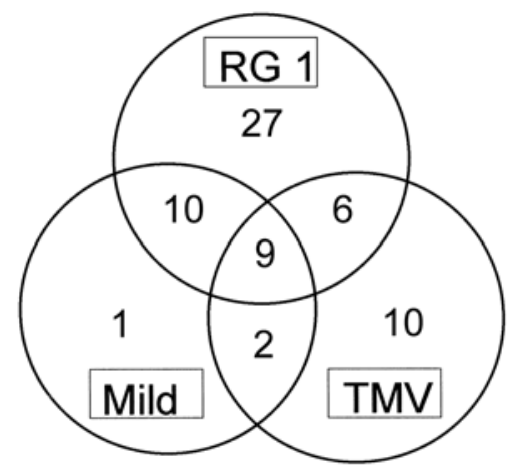

Fig. 4. Venn diagram showing the number of overlapping and nonoverlapping genes that show differential expression patterns during Potato spindle tuber viroid or Tobacco mosaic virus infection.
Langland et al. 1998; Vera and Conejero 1990), and iv) direct activation or inactivation of gene expression.

PSTVd can induce and be the target of host RNA silencing in infected tomato (Itaya et al. 2001; Papaefthimiou et al. 2001). Papaefthimiou and associates (2001) postulated that RNA silencing triggered by viroids also silences host genes, based on sequence homology, as one of the mechanisms of viroid pathogenicity. However, we did not detect homology-dependent RNA silencing of host genes in our current experiment based on sequence alignment between PSTVd and all of the suppressed genes.

Results from our current study suggest the possibility that viroids alter host gene expression patterns at the transcriptional or posttranscriptional level, leading to disease formation. However, this does not exclude other possibilities, such as translational or posttranslational regulations of host gene expression as causes of symptom expression. PSTVd induces phosphorylation of the double stranded RNA-dependent protein kinase (pPKR) in tomato (Hiddinga et al. 1988). The pPKR is differentially activated in vitro by different strains of PSTVd (Diener et al. 1993). Langland and associates (1998) reported that the pPKR accumulated in the cytoplasm and was activated by phosphorylation during viroid infection. The regulatory role of small temporal RNA (stRNA) in translation has been described in Caenorhabditis elegans (Olsen and Ambros 1999; Wightman et al. 1993). stRNA binds directly to a target mRNA to repress its translation, and such regulation is essential for proper development of an organism (Reinhart 2000). Therefore, a viroid may directly repress translation of one or more host mRNAs by a similar mechanism. These possibilities need to be tested by either biochemical or proteomic approaches or both.

We have demonstrated that viroid infection can alter the expression patterns of many host genes. Viroids must rely entirely on host systems for their infection and probably alter host gene expression patterns by interacting with host factors and regulatory systems. Viroids do interact with a number of host proteins, including histones (Wolff et al. 1985), ribosomal protein S25 (Werner et al. 1995), and phloem protein 2 (Gómez and Pallás 2001; Owens et al. 2001). Further analysis of host proteins that interact with viroids should help understand the significance of such interactions. In parallel, further investigation on genes whose expression is specifically altered during viroid infection will be important to understand viroid pathogenicity. Such studies may also provide novel insights about endogenous RNA-based gene regulation in plants.

\section{MATERIALS AND METHODS}

\section{Plant material and growth conditions.}

Tomato (Lycopersicon esculentum Mill cv. Rutgers) was grown in a growth chamber with an $18 \mathrm{~h}$ light $\left(26^{\circ} \mathrm{C}\right)$ and $6 \mathrm{~h}$ dark $\left(26^{\circ} \mathrm{C}\right)$ cycle. Plants were watered daily with commercial plant nutrients as instructed by the manufacturer (Miracle-Gro for Tomatoes; Scotts Miracle-Gro Products Inc., Marysville, OH, U.S.A.).

\section{In vitro transcription of viroid RNA and inoculation of plants.}

Plasmids containing cDNAs of PSTVd ${ }^{\text {Mild }}$ and PSTVd ${ }^{R G 1}$ (provided by R. Owens, USDA/ARS, Beltsville, MD, U.S.A.) were linealized by HindIII digestion as templates for in vitro transcription using T7 RNA polymerase (Promega, Madison, WI, U.S.A.) following the manufacturer's instructions. The transcripts were inoculated onto each cotyledon of a 9- to 10day-old tomato plant (80 ng per plant). TMV was inoculated as virions (1.5 $\mu \mathrm{g}$ virions per plant). diethylpyrocarbonate- $\mathrm{H}_{2} \mathrm{O}$ was used in mock inoculations. 


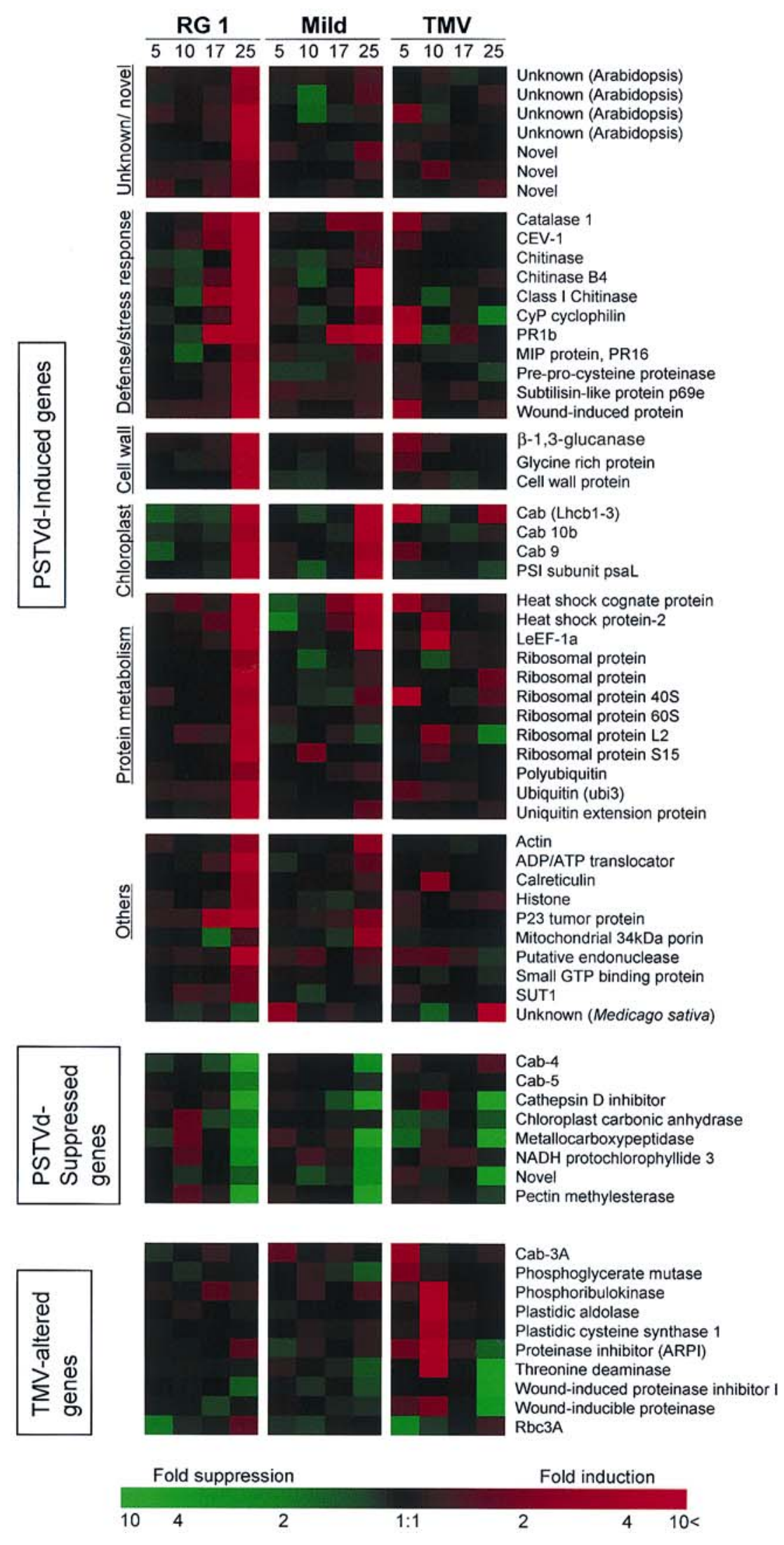

Fig. 5. Temporal expression patterns of differentially expressed genes. Sixty-five genes whose mRNA levels changed reproducibly in response to Potato spindle tuber viroid or Tobacco mosaic virus infection are presented. The pathogens used for infection as well as the days post inoculation are indicated at the top of the columns. The expression pattern of each gene is displayed as a horizontal strip. Induced or enhanced expression is indicated by red, and suppressed or reduced expression is indicated by green. Missing data points, either nonreproducible or low signal data are represented by gray. The expression level was determined by averaging four data points from each gene. Tables 1 and 2 show the genes listed in the same order with GenBank accession numbers for each gene. Image display was created using the Cluster and Tree View software available from M. Eisen's lab website. 


\section{Plant tissue sampling.}

Leaf samples were collected from individual plants at 5, 10, 17, and $25 \mathrm{dpi}$. At least one half of each leaf from all branches of a plant was collected, except for old yellowing leaves. Leaf samples were wrapped in aluminum foil immediately after detachment, frozen in liquid nitrogen, and stored at $-80^{\circ} \mathrm{C}$.

\section{Dot blot analysis.}

A digoxigenin (DIG)-labeled (-)-strand PSTVd probe was generated by in vitro transcription as described above, using EcoRI-linearized plasmid pST65-B5 (Owens et al. 1986) as template and DIG-11-dUTP (Roche Diagnostics, Indianapolis, IN, U.S.A.) at a final concentration of $0.1 \mathrm{mM}$.

Viroid infection was confirmed by dot blot analysis at 17 dpi. A piece of leaf tissue $\left(5 \mathrm{~mm}^{2}\right)$ was homogenized in $50 \mu \mathrm{l}$ of AMES buffer $(0.5 \mathrm{M}$ sodium acetate, $10 \mathrm{mM} \mathrm{MgCl}, 20 \%$ ethanol, $3 \%$ sodium dodecyl sulfate (SDS), and $1 \mathrm{M} \mathrm{NaCl}$ ) in an Eppendorf tube. The homogenate was incubated at room temperature for $10 \mathrm{~min}$, then extracted with chloroform:isoamyl alcohol $(24: 1 ; 200 \mu \mathrm{l})$. The extract $(2 \mu \mathrm{l})$ was blotted onto a Hybond $\mathrm{N}^{+}$nylon membrane (Amersham Biosciences, Piscataway, NJ, U.S.A.) and UV-crosslinked.

Table 1. Expression profile of genes that are induced by Potato spindle tuber viroid (PSTVd) infection at 25 days post inoculation

\begin{tabular}{|c|c|c|c|c|c|c|}
\hline \multirow[b]{2}{*}{ GenBank accession no. } & \multirow[b]{2}{*}{ No. of clones found ${ }^{b}$} & \multirow[b]{2}{*}{ BLAST hit ${ }^{c}$} & \multirow[b]{2}{*}{ Coded protein ${ }^{d}$} & \multicolumn{3}{|c|}{ Induction fold $^{\mathrm{a}}$} \\
\hline & & & & RG1 & Mild & TMV \\
\hline \multicolumn{7}{|l|}{ Unknown or novel } \\
\hline BM956703 & 1 & AY080833 & Arabidopsis unknown function & 2.4 & 1.6 & 0.9 \\
\hline BM956704 & 1 & AC007399 & Arabidopsis unknown function & 2.3 & 1.7 & 1.4 \\
\hline BM956707 & 1 & AL391151 & Arabidopsis unknown function & 3.0 & 1.3 & 1.2 \\
\hline BM956723 & 1 & $\mathrm{AC} 015450$ & Arabidopsis unknown function & 3.2 & 0.9 & 1.0 \\
\hline BM956700 & 1 & - & Novel & 2.7 & 1.9 & 1.1 \\
\hline BM956711 & 1 & - & Novel & 2.3 & 1.5 & 1.2 \\
\hline BM956714 & 1 & - & Novel & 2.2 & 0.9 & 1.6 \\
\hline \multicolumn{7}{|l|}{ Defense/stress response } \\
\hline BM956635 & 4 & M93719 & Catalase 1 & 9.9 & 2.0 & 0.9 \\
\hline BM956661 & 1 & X71593 & $\mathrm{CEV}$ induced protein $(\mathrm{CEV}-1)$ & 5.0 & 1.7 & 0.9 \\
\hline BM956715 & 1 & Z15141 & Chitinase & 4.2 & 1.6 & 1.0 \\
\hline BM956652 & 1 & U02608 & Chitinase B4 & 4.1 & 3.0 & 1.3 \\
\hline BM956639 & 1 & AF043247 & ClassI Chitinase & 7.6 & 3.3 & 1.0 \\
\hline BM956705 & 2 & M55019 & CyP cyclophilin & 3.1 & 2.0 & 0.5 \\
\hline BM956622 & 8 & Y08804 & PR-1b & 64.6 & 11.9 & - \\
\hline BM956699 & 1 & Y18312 & Intrinsic protein, PR16 & 2.3 & 1.7 & - \\
\hline BM956674 & 3 & Z14028 & Pre-pro-cystein proteinase & 2.6 & 1.4 & 0.7 \\
\hline BM956702 & 1 & Y10149 & Subtilisin-like protein, p69e & 2.6 & 1.4 & 0.9 \\
\hline BM956647 & 2 & U89764 & Wound-induced protein & 3.7 & 1.5 & 1.4 \\
\hline \multicolumn{7}{|l|}{ Cell wall } \\
\hline BM956662 & 3 & X74906 & $\beta$-1,3-glucanase & 5.6 & 1.4 & 1.1 \\
\hline BM956712 & 1 & X55689 & Glycine rich protein & 2.7 & 1.2 & 1.0 \\
\hline BM956618 & 1 & Y19032 & Cell wall protein & 2.8 & 1.1 & 0.9 \\
\hline \multicolumn{7}{|l|}{ Chloroplast } \\
\hline BM956706 & 2 & $\mathrm{U} 21112$ & $C a b$ (Lhcb1-3) & 7.3 & 4.7 & 2.2 \\
\hline BM956724 & 1 & M32606 & $\mathrm{Cab} 10 \mathrm{~b}$ & 2.5 & 2.8 & 1.3 \\
\hline BM956681 & 1 & X61287 & Cab 9 & 3.0 & 2.5 & 0.9 \\
\hline BM956683 & 1 & D83007 & PS I subunit psaL & 4.1 & 5.9 & 0.7 \\
\hline \multicolumn{7}{|l|}{ Protein metabolism } \\
\hline BM956633 & 1 & M96549 & Heat shock cognate protein & 8.8 & 3.7 & 1.3 \\
\hline BM956659 & 1 & X54030 & Heat shock protein-2 & 5.2 & 2.6 & 0.9 \\
\hline BM956617 & 5 & X14449 & LeEF-1a & 5.1 & 3.7 & 1.2 \\
\hline BM956676 & 1 & AF026079 & Ribosomal protein & 2.3 & 1.5 & 1.2 \\
\hline BM956708 & 1 & AJ278460 & Ribosomal protein & 2.0 & 1.5 & 1.9 \\
\hline BM956658 & 1 & AY054622 & Ribosomal protein $40 \mathrm{~S}$ & 2.8 & 1.8 & 1.7 \\
\hline BM956713 & 1 & AY081305 & Ribosomal protein $60 \mathrm{~S}$ & 2.5 & 1.4 & 1.2 \\
\hline BM956656 & 1 & X64562 & Ribosomal protein L2 & 2.7 & 0.7 & 0.5 \\
\hline BM956663 & 1 & Z23161 & Ribosomal protein S15 & 2.7 & 1.0 & 1.1 \\
\hline BM956620 & 1 & X64344 & Polyubiquitin & 3.4 & 1.5 & 1.0 \\
\hline BM956710 & 1 & X58253 & Ubiquitin (ubi3) & 2.2 & 1.1 & 1.1 \\
\hline BM956634 & 1 & Y10024 & Ubiquitin extension protein & 3.1 & 1.8 & 1.3 \\
\hline \multicolumn{7}{|l|}{ Others } \\
\hline BM956643 & 2 & U60481 & Actin (Tom51) & 2.3 & 2.2 & 1.0 \\
\hline BM956675 & 2 & U89839 & ADP/ATP translocator & 3.1 & 1.8 & 1.1 \\
\hline BM956641 & 1 & Z71395 & Calreticulin & 2.4 & 1.5 & 1.1 \\
\hline BM956737 & 1 & X83422 & Histone & 2.4 & 1.2 & 1.5 \\
\hline BM956642 & 3 & Z37160 & Homolog to human P23 tumor protein & 4.9 & 2.1 & 1.1 \\
\hline BM956709 & 1 & X80386 & Mitochondrial $34 \mathrm{kDa}$ porin & 1.5 & 2.4 & - \\
\hline BM956623 & 1 & AJ293762 & Putative endonuclease & 4.5 & 1.6 & 0.7 \\
\hline BM956721 & 1 & AF210431 & Small GTP binding protein & 2.0 & 1.4 & 0.8 \\
\hline BM956741 & 1 & X82275 & Sucrose transporter 1 (SUT1) & 2.0 & 1.0 & 1.0 \\
\hline
\end{tabular}

${ }^{a}$ Induction folds as calculated by the log regression method. The average of four data points of each gene is presented. Induction folds greater than 2.0 are in bold.

${ }^{b}$ Number of clones of the same gene showing the same expression pattern found in our library.

${ }^{c}$ The accession numbers of the registered genes that share the highest homology with identified clones.

${ }^{\mathrm{d}}$ Putative function of the clone. 
Dot blot was performed using reagents purchased from Boehringer Mannheim (Indianapolis, IN, U.S.A.). Prehybridization was carried out at $65^{\circ} \mathrm{C}$ for $1 \mathrm{~h}$. The DIG-labeled viroid RNA probe was then added to the hybridization solution at a final concentration of $400 \mathrm{ng}$ per $\mathrm{ml}$. The hybridization was carried out at $55^{\circ} \mathrm{C}$ for 12 to $18 \mathrm{~h}$, followed by stringent washes in $2 \times \mathrm{SSC}(1 \times \mathrm{SSC}$ is $0.15 \mathrm{M} \mathrm{NaCl}$ plus $0.015 \mathrm{M}$ sodium citrate) twice at $55^{\circ} \mathrm{C}$ for $15 \mathrm{~min}$ and then with $0.1 \% \mathrm{SSC} / 0.1 \%$ SDS at $65^{\circ} \mathrm{C}$ for $30 \mathrm{~min}$. Hybridization signal was detected using the DIG Nucleic Acid Detection Kit (Boehringer Mannheim) following the manufacturer's instructions.

\section{Total RNA extraction from plants.}

Total RNA was extracted from leaves, using Trizol (Gibco BRL, Rockville, MD, U.S.A.) following the manufacturer's instructions. The RNA solution was split into aliquots and stored at $-80^{\circ} \mathrm{C}$. To normalize variations among individual plants, total RNA was extracted from leaves of a pool of 3 to 5 plants with the same treatment (i.e., viroid inoculation, mock inoculation, or virus inoculation). At least three independent total RNA pools were prepared from each treatment. One pool was used for macroarray construction, and the other pools were used to prepare complex probes for independent hybridization experiments as described below.

\section{Isolation of mRNA and construction of subtracted cDNA libraries.}

From the total RNA, mRNA was isolated with the Dynabeads mRNA Purification Kit (Dynal, Lake Success, NY, U.S.A.) following the manufacturer's instructions. Subtracted cDNA libraries were constructed by using the PCR-Select cDNA Subtraction Kit (Clontech, Palo Alto, CA, U.S.A.) following the manufacturer's instructions. Subtracted cDNAs were shotgun-cloned into the TOPO TA Cloning vector (Invitrogen Corp., Carlsbad, CA, U.S.A.). The ligation mixture $(2 \mu \mathrm{l})$ was used to transform $50 \mu \mathrm{l}$ of Escherichia coli DH5 $\alpha$ competent cells as instructed by the vendor (Invitrogen). If the number of colonies obtained was less than 20 , the subtracted cDNAs were diluted four times and subjected to shotgun-cloning again as described above.

\section{Plasmid isolation and macroarray construction.}

Single E. coli colonies harboring the subtracted cDNAs were picked manually and used to inoculate $1.5 \mathrm{ml}$ of Luria-Bertani medium containing ampicillin $(100 \mu \mathrm{g}$ per $\mathrm{ml})$ in 96 -well blocks. Bacteria were grown for $20 \mathrm{~h}$ at $37^{\circ} \mathrm{C}$. Bacterial culture $(100 \mu \mathrm{l})$ was used to make $15 \%$ glycerol bacterial stock using a BIOMEK 2000 robotic workstation (Beckman Instruments, Inc., Fullerton, CA, U.S.A.). The rest of the bacterial culture was centrifuged at
2,500 rpm for $10 \mathrm{~min}$ at $4{ }^{\circ} \mathrm{C}$ to harvest cells. Plasmids were isolated by an alkaline lysis method using a 96-well plate format on the BIOMEK 2000 robotic workstation. Typically, 0.05 to $0.3 \mu \mathrm{g}$ of plasmid per $\mu \mathrm{l}$ was obtained.

Plasmids from eight microtiter plates were spotted in duplicate in a $4 \times 4$ format on an $8 \times 12 \mathrm{~cm}$ Hybond $\mathrm{N}^{+}$nylon filter (Amersham Biosciences). This was accomplished with a 96pin plate (BIOMEK Part number 609004) on the BIOMEK 2000 robotic workstation. Filters were submerged in a denaturation solution $(1.5 \mathrm{M} \mathrm{NaCl}$ and $0.5 \mathrm{M} \mathrm{NaOH})$ for 2 min and in a neutralization solution $(1.5 \mathrm{M} \mathrm{NaCl}$ and $0.5 \mathrm{M}$ Tris- $\mathrm{HCl}, \mathrm{pH}$ $8.0)$ for $5 \mathrm{~min}$ and were rinsed in a $0.2 \mathrm{M}$ Tris- $\mathrm{HCl}(\mathrm{pH} 7.5)$ to $2 \times$ SSC solution for no more than $30 \mathrm{~s}$. The filters were briefly blotted on a piece of Whatman 3MM paper, crosslinked by $120,000 \mathrm{~J}$ UV light and stored at $-20^{\circ} \mathrm{C}$.

\section{Preparation and labeling of complex probes.}

The mRNA from 20 to $160 \mu \mathrm{g}$ of total RNA was isolated by using an Oligotex mRNA Kit (Qiagen Inc., Valencia, CA, U.S.A.). The purified mRNAs $(0.5$ to $2.0 \mu \mathrm{g})$ and Oligo(dT) $)_{12-18}$ primer $(2 \mu \mathrm{g})$ (Invitrogen Corp.) were mixed and incubated at $70^{\circ} \mathrm{C}$ for $10 \mathrm{~min}$, then cooled on ice to allow annealing. The complex probes were prepared by reverse transcription using SuperScriptII (Invitrogen) in the presence of $60 \mu \mathrm{Ci}$ of $\left[\alpha-{ }^{33} \mathrm{P}\right]$ dATP and $60 \mu \mathrm{Ci}$ of $\left[\alpha^{-33} \mathrm{P}\right] \mathrm{dCTP}$ (Perkin Elmer Life Sciences, Boston). The reaction was stopped by adding $1 \mu \mathrm{l}$ of $0.2 \mathrm{M}$ EDTA ( $\mathrm{pH}$ 8.0). Unincorporated radioactive nucleotides were removed by passing the reaction mixture through G-50 spin columns (Amersham Biosciences). Typically, 50 to $80 \%$ of radioactive nucleotides were incorporated into the probes giving a total probe activity of $0.4 \times 10^{8}$ to $1.0 \times 10^{8} \mathrm{cpm}$. The probes were stored at $-20^{\circ} \mathrm{C}$.

\section{Hybridization conditions.}

Filters were prehybridized in a hybridization solution $(0.5 \mathrm{M}$ $\mathrm{NaHPO}_{4}, \mathrm{pH} 7.2,1 \mathrm{mM}$ EDTA, $7 \%$ SDS) at $55^{\circ} \mathrm{C}$ for at least 1 h. Probes (total activity of $1.0 \times 10^{7}$ to $3.0 \times 10^{7} \mathrm{cpm}$ ) were boiled for $10 \mathrm{~min}$ and then added to the filters at a final concentration of $1.0 \times 10^{6}$ to $4.0 \times 10^{6} \mathrm{cpm}$ per ml. Hybridization was carried out at $55^{\circ} \mathrm{C}$ for 18 to $24 \mathrm{~h}$. Filters were washed for $15 \mathrm{~min}$ in $1.5 \times \mathrm{SSPE}(1 \times \mathrm{SSPE}$ is $0.18 \mathrm{M} \mathrm{NaCl}, 10 \mathrm{mM}$ $\mathrm{NaPO}_{4}$, and $2 \mathrm{mM}$ EDTA [pH 7.7]) and $0.2 \%$ SDS, $15 \mathrm{~min}$ in $0.5 \times \mathrm{SSPE}$ and $0.2 \% \mathrm{SDS}$, and $15 \mathrm{~min}$ in $0.2 \times \mathrm{SSPE}$ and $0.1 \%$ SDS. All washes were carried out at $65^{\circ} \mathrm{C}$. Dried filters were exposed to phosphor screens (Molecular Dynamics, Sunnyvale, CA, U.S.A.) for 12 to $72 \mathrm{~h}$. Two to three independent hybridizations with the complex probes prepared from different total RNA pools (discussed above) were performed for each sample set.

Table 2. Expression profile of genes that are suppressed by Potato spindle tuber viroid (PSTVd) infection at 25 days post inoculation

\begin{tabular}{|c|c|c|c|c|c|c|}
\hline \multirow[b]{2}{*}{ GenBank accession no. } & \multirow[b]{2}{*}{ No. of clones found ${ }^{b}$} & \multirow[b]{2}{*}{ BLAST hit ${ }^{\mathrm{c}}$} & \multirow[b]{2}{*}{ Coded protein ${ }^{\mathrm{d}}$} & \multicolumn{3}{|c|}{ Suppression fold ${ }^{\mathrm{a}}$} \\
\hline & & & & RG1 & Mild & TMV \\
\hline BM956672 & 4 & M17558 & $C a b-4$ & 2.9 & 2.3 & 0.6 \\
\hline BM956735 & 6 & M17559 & $C a b-5$ & 2.0 & 1.3 & 0.9 \\
\hline BM956733 & 1 & X67843 & Cathepsin D inhibitor & 3.0 & 3.8 & 9.8 \\
\hline BM956637 & 1 & M94135 & Chloroplast carbonic anhydrase & 2.0 & 1.2 & 1.6 \\
\hline BM956687 & 1 & X59282 & Metallocarboxypeptidase & 2.5 & 3.4 & 7.3 \\
\hline BM956666 & 1 & AF243523 & NADH protochlorophyllide 3 & 2.3 & 2.3 & 1.2 \\
\hline BM956717 & 1 & - & Novel & 1.7 & 2.4 & 2.8 \\
\hline BM956669 & 4 & S66607 & Pectinmethylesterase-like sequence & 3.9 & 3.1 & 1.4 \\
\hline
\end{tabular}

${ }^{a}$ Suppression folds as calculated by the log regression method. The average of four data points of each gene is presented. Suppression folds greater than 2.0 are in bold.

${ }^{\mathrm{b}}$ Number of clones of the same gene showing the same expression pattern found in our library.

${ }^{\mathrm{c}}$ The accession numbers of the registered genes that share the highest homology with identified clones.

${ }^{\mathrm{d}}$ Putative function of the clone. 
Imaging and analysis of hybridization signals.

The phosphor screens were scanned with the phosphoimager system Storm 820 (Molecular Dynamics). The Array Vision 5.1 software (IMAGING Research Inc., St. Catharines, Ontario, Canada) was used for quantification of signal intensities. This software performs dot identification, dot quantification, and local background signal subtraction.

Normalization of signal intensities was conducted based on the log space linear regression normalization method available on the Arabidopsis Functional Genomics Consortium website. The Excel file template for calculation was provided by $\mathrm{S}$. Agarie (Saga University, Japan). Clones that showed more than twofold reproducible (for duplicates within a macroarray and between macroarrays after independent hybridization) enhanced or decreased expressions as compared with the control were chosen for sequencing. Dots with weak hybridization signals that were less than the median of signal intensities of all of the dots on the entire membrane were removed from analysis, because the expression ratio of such weak signals might not be reliable. Because of the stringent criteria used for selection of clones, some differentially expressed genes might have been eliminated if they were rare transcripts or if the amount of DNA spotted on the membrane was low. Of the 172 clones sequenced, four were revealed to be chimeric (more than one gene ligated and inserted into the vector) and required further subcloning to identify the differentially expressed genes. DNA sequence data were subjected to a BLAST database search to identify the genes or to assign putative functions.

The expression levels of each gene during time course was represented in color coding using the Cluster and Tree view software (Eisen et al. 1998), which is available from M. Eisen's lab website.

\section{ACKNOWLEDGMENTS}

We thank S. Agarie, J. Cushman, J. Liu, and L. Wang for providing their expertise in bioinformatics. We thank Molecular Analysis and Synthesis Support Group in Samuel Roberts Noble Foundation for assistance with DNA sequencing. We are grateful to R. Owens for providing the PSTVd cDNAs. This work was supported by grants from the United States Department of Agriculture National Research Initiative Competitive Grants Program (No. 97-35303-4519 and 2001-35303-11073 to B. D.) and from Samuel Roberts Noble Foundation.

\section{LITERATURE CITED}

Akopyants, N. S., Fradkov, A., Diatchenko, L., Hill, J. E., Siebert, P. D., Lukyanov, S. A., Sverdlov, E. D., and Berg, D. E. 1998. PCR-based subtractive hybridization and differences in gene content among strains of Helicobacter pylori. Proc. Natl. Acad. Sci. U.S.A. 95:1310813113.

Aranda, M. A., Escaler, M., Wang, D., and Maule, A. J. 1996. Induction of HSP70 and polyubiquitin expression associated with plant virus replication. Proc. Natl. Acad. Sci. U.S.A. 93:15289-15293.

Bernard, K., Auphan, N., Granjeaud, S., Victorero, G., Schmitt-Verhulst, A. M., Jordan, B. R., and Nguyen, C. 1996. Multiplex messenger assay: Simultaneous, quantitative measurement of expression of many genes in the context of $\mathrm{T}$ cell activation. Nucleic Acids Res. 24:14351442.

Camacho-Henriquez, A., and Sänger, H. L. 1984. Purification and partial characterization of the major "pathogenesis-related" tomato leaf protein P14 from potato spindle tuber viroid (PSTV)-infected tomato leaves. Arch. Virol. 81:263-284.

Chang, Y. C., and Walling, L. L. 1992. Chlorophyll a/b-binding protein genes are differentially expressed during soybean development. Plant Mol. Biol. 19:217-230.

Clarke, S. R., Staiger, C. J., Gibbon, B. C., and Franklin-Tong, V. E. 1998. A potential signaling role for profilin in pollen of Papaver rhoeas. Plant Cell 10:967-979.

Covey, S. N., Al-Kaff, N. S., Lángara, A., and Turner, D. S. 1997. Plants combat infection by gene silencing. Nature 385:781-782.

Da Graça, J. V., and Martin, M. M. 1981. Ultrastructural changes in avo- cado leaf tissue infected with avocado sunblotch. Phytopathol. Z. 102:185-194.

Diatchenko, L., Lau, Y. F., Campbell, A. P., Chenchik, A., Moqadam, F., Huang, B., Lukyanov, S., Lukyanov, K., Gurskaya, N., Sverdlov, E. D., and Siebert, P. D. 1996. Suppression subtractive hybridization: A method for generating differentially regulated or tissue-specific cDNA probes and libraries. Proc. Natl. Acad. Sci. U.S.A. 93:6025-6030.

Dickson, E. 1981. A model for the involvement of viroids in RNA splicing. Virology 115:216-221.

Diener, T. O. 1981. Are viroids escaped introns? Proc. Natl. Acad. Sci. U.S.A. 78:5014-5015.

Diener, T. O. 2001. The viroid: Biological oddity or evolutionary fossil? Adv. Virus Res. 57:137-184.

Diener, T. O., Hammond, R. W., Black, T., and Katze, M. G. 1993. Mechanism of viroid pathogenesis: Differential activation of the interferon-induced, double-stranded RNA-activated, M(r) 68,000 protein kinase by viroid strains of varying pathogenicity. Biochimie 75:533-538.

Eisen, M. B., Spellman, P. T., Brown, P. O., and Botstein, D. 1998. Cluster analysis and display of genome-wide expression patterns. Proc. Natl. Acad. Sci. U.S.A. 95:14863-14868.

Escaler, E., Aranda, M. A., Roberts, I. M., Thomas, C. L., and Maule, A. J. 2000a. A comparison between virus replication and abiotic stress (heat) as modifiers of host gene expression in pea. Mol. Plant Pathol. 1:159-168.

Escaler, M., Aranda, M. A., Thomas, C. L., and Maule, A. J. 2000b. Pea embryonic tissues show common responses to the replication of a wide range of viruses. Virology 267:318-325.

Flores, R., Di Serio, F., and Hernández, C. 1997. Viroids: The non-encoding genomes. Seminars Virol. 8:65-73.

Fritig, B., Heitz, T., and Legrand, M. 1998. Antimicrobial proteins in induced plant defense. Curr. Opin. Immunol. 10:16-22.

Gadea, J., Mayda, M. E., Conejero, V., and Vera, P. 1996. Characterization of defense-related genes ectopically expressed in viroid-infected tomato plants. Mol. Plant-Microbe Interact. 9:409-415.

García Breijo, F. J., Garro, R., and Conejero, V. 1990. C7(P32) and C6 (P34) PR proteins induced in tomato leaves by citrus exocortis viroid infection are chitinases. Physiol. Mol. Plant Pathol. 36:249-260.

Garnsey, S. M., and Randles, J. W. 1987. Biological interactions and agricultural implications of viroids. Pages 127-160 in: Viroids and viroidlike pathogens. CRC Press, Boca Raton, FL, U.S.A.

Geng, M., Wallrapp, C., Muller-Pillasch, F., Frohme, M., Hoheisel, J. D., and Gress, T. M. 1998. Isolation of differentially expressed genes by combining representational difference analysis (RDA) and cDNA library arrays. Biotechniques 25:434-438.

Genoud, T., and Métraux, J. P. 1999. Crosstalk in plant cell signaling: Structure and function of the genetic network. Trends Plant Sci. 4:503 507.

Gómez, G., and Pallás, V. 2001. Identification of an in vitro ribonucleoprotein complex between a viroid RNA and a phloem protein from cucumber plants. Mol. Plant-Microbe Interact. 14:910-913.

Granell, A., Bellés, J. M., and Conejero, V. 1987. Induction of pathogenesis-related proteins in tomato by citrus exocortis viroid, silver ion and ethephon. Physiol. Mol. Plant Pathol. 31:83-90.

Gruner, R., Fels, A., Qu, F., Zimmat, R., Steger, G., and Riesner, D. 1995. Interdependence of pathogenicity and replicability with potato spindle tuber viroid. Virology 209:60-69.

Gu, Y.-Q., and Martin, G. B. 1998. Molecular mechanisms involved in bacterial speck disease resistance of tomato. Phil. Trans. R. Soc. Lond. B. 353:1455-1461.

Hammond, R. W. 1992. Analysis of the virulence modulating region of potato spindle tuber viroid (PSTVd) by site-directed mutagenesis. Virology 187:654-662.

Hammond, R. W., and Owens, R. A. 1987. Mutational analysis of potato spindle tuber viroid reveals complex relationships between structure and infectivity. Proc. Natl. Acad. Sci. U.S.A. 84:3967-3971.

Hammond, R. W., and Zhao, Y. 2000. Characterization of a tomato protein kinase gene induced by infection by Potato spindle tuber viroid. Mol. Plant-Microbe Interact. 13:903-910.

Hari, V. 1980. Ultrastructure of Potato spindle viroid-infected tomato leaf tissue. Phytopathology 70:385-387.

Havelda, Z., and Maule, A. J. 2000. Complex spatial responses to cucumber mosaic virus infection in susceptible Cucurbita pepo cotyledons. Plant Cell 12:1975-1986.

Herbers, K., Meuwly, P., Metraux, J. P., and Sonnewald, U. 1996. Salicylic acid-independent induction of pathogenesis-related protein transcripts by sugars is dependent on leaf developmental stage. FEBS (Fed. Eur. Biochem. Soc.) Lett. 397:239-244.

Hiddinga, H. J., Crum, C. J., Hu, J., and Roth, D. A. 1988. Viroid-induced phosphorylation of a host protein related to a dsRNA-dependent protein kinase. Science 241:451-453. 
Hu, Y., Feldstein, P. A., Hammond, J., Hammond, R. W., Bottino, P. J., and Owens, R. A. 1997. Destabilization of potato spindle tuber viroid by mutations in the left terminal loop. J. Gen. Virol. 78:1199-1206.

Hunt, M. D., and Ryals, J. A. 1996. Systemic acquired resistance signal transduction. Crit. Rev. Plant Sci. 15:583-606.

Itaya, A., Folimonov, A., Matsuda, Y., Nelson, R. S., and Ding, B. 2001 Potato spindle tuber viroid as inducer of RNA silencing in infected tomato. Mol. Plant-Microbe Interact. 14:1332-1334.

Jordá, L., Conejero, V., and Vera, P. 2000. Characterization of P69E and $\mathrm{P} 69 \mathrm{~F}$, two differentially regulated genes encoding new members of the subtilisin-like proteinase family from tomato plants. Plant Physiol. 122:67-74.

Jordan, B. R. 1998. Large-scale expression measurement by hybridization methods: From high-density membranes to "DNA chips". J. Biochem. 124:251-258.

Lanfranchi, G., Muraro, T., Caldara, F., Pacchioni, B., Pallavicini, A., Pandolfo, D., Toppo, S., Trevisan, S., Scarso, S., and Valle, G. 1996. Identification of 4370 expressed sequence tags from a 3 '-end-specific cDNA library of human skeletal muscle by DNA sequencing and filter hybridization. Genome Res. 6:35-42.

Langland, J., Langland, L., and Roth, D. 1998. Differential localization and accumulation of the plant double stranded RNA-dependent protein kinase during virus infection. Plant Physiol. Biochem. 36:395-400.

Lawson, R. H., and Hearon, S. S. 1971. Ultrastructure of chrysanthemum stunt virus-infected and stunt-free mistletoe chrysanthemum. Phytopathology 61:653-656.

Lee, R. C., and Ambros, V. 2001. An extensive class of small RNAs in Caenorhabditis elegans. Science 294:862-864.

Loss, P., Schmitz, M., Steger, G., and Riesner, D. 1991. Formation of a thermodynamically metastable structure containing hairpin II is critical for infectivity of potato spindle tuber viroid RNA. EMBO (Eur. Mol. Biol. Organ.) J. 10:719-727.

Lucas, J., Camacho Henriquez, A. C., Lottspeich, F., Henschen, A., and Sänger, H. L. 1985. Amino acid sequence of the 'pathogenesis-related leaf protein p14 from viroid-infected tomato reveals a new type of structurally unfamiliar proteins. EMBO (Eur. Mol. Biol. Organ.) J. 4:2745-2749

Martin, G. B. 1999. Functional analysis of plant disease resistance genes and their downstream effectors. Curr. Opin. Plant Biol. 2:273-279.

McCafferty, H. R., and Talbot, N. J. 1998. Identification of three ubiquitin genes of the rice blast fungus Magnaporthe grisea, one of which is highly expressed during initial stages of plant colonization. Curr. Genet. 33:352-361.

Momma, T., and Takahashi, T. 1982. Ultrastructure of hop stunt viroid-infected leaf tissue. Phytopathol. Z. 104:211-221.

Olsen, P. H., and Ambros, V. 1999. The lin-4 regulatory RNA controls developmental timing in Caenorhabditis elegans by blocking LIN-14 protein synthesis after the initiation of translation. Dev. Biol. 216:671680

Owens, R. A., Blackburn, M., and Ding, B. 2001. Possible involvement of the phloem lectin in long-distance viroid movement. Mol. PlantMicrobe Interact. 14:905-909.

Owens, R. A., Chen, W., Hu, Y., and Hsu, Y. H. 1995. Suppression of potato spindle tuber viroid replication and symptom expression by mutations which stabilize the pathogenicity domain. Virology 208:554-564

Owens, R. A., Hammond, R. W., Gardner, R. C., Kiefer, M. C. Thompsom, S. M., and Cress, D. E. 1986. Site-specific mutagenesis of potato spindle tuver viroid cDNA. Plant Mol. Biol. 6:179-192.

Owens, R. A., Steger, G., Hu, Y., Fels, A., Hammond, R. W., and Riesner, D. 1996. RNA structural features responsible for potato spindle tuber viroid pathogenicity. Virology 222:144-158.

Paliwal, Y. C. and Singh, R. P. 1981. Cytopathological changes induced by potato spindle tuber viroid in Scopolia sinensis. Can. J. Bot. 59:677-682.

Papaefthimiou, I., Hamilton, A., Denti, M., Baulcombe, D., Tsagris, M., and Tabler, M. 2001. Replicating potato spindle tuber viroid RNA is accompanied by short RNA fragments that are characteristic of posttranscriptional gene silencing. Nucleic Acids Res. 29:2395-2400.

Piétu, G., Alibert, O., Guichard, V., Lamy, B., Bois, F., Leroy, E., Mariage-Sampson, R., Houlgatte, R., Soularue, P., and Auffray, C. 1996. Novel gene transcripts preferentially expressed in human muscles revealed by quantitative hybridization of a high density cDNA array. Genome Res. 6:492-503.

Qu, F., Heinrich, C., Loss, P., Steger, G., Tien, P., and Riesner, D. 1993. Multiple pathways of reversion in viroids for conservation of structural elements. EMBO (Eur. Mol. Biol. Organ.) J. 12:2129-2139.

Ratcliff, F., Harrison, B. D., and Baulcombe, D. C. 1997. A similarity between viral defense and gene silencing in plants. Science 276:15581560 .
Reinhart, B. J., Slack, F. J., Basson, M., Pasquinelli, A. E., Bettinger, J. C., Rougvie, A. E., Horvitz, H. R., and Ruvkun, G. 2000. The 21-nucleotide let-7 RNA regulates developmental timing in Caenorhabditis elegans. Nature 403:901-906.

Rodrigo, I., Vera, P., Frank, R., and Conejero, V. 1991. Identification of the viroid-induced tomato pathogenesis-related (PR) protein P23 as the thaumatin-like tomato protein NP24 associated with osmotic stress. Plant Mol. Biol. 16:931-934.

Rodrigo, I., Vera, P., Tornero, P., Hernandez-Yago, J., and Conejero, V. 1993. cDNA cloning of viroid-induced tomato pathogenesis-related protein P23. Characterization as a vacuolar antifungal factor. Plant Physiol. 102:939-945.

Schenk, P. M., Kazan, K., Wilson, I., Anderson, J. P., Richmond, T. Somerville, S. C., and Manners, J. M. 2000. Coordinated plant defense responses in Arabidopsis revealed by microarray analysis. Proc. Natl. Acad. Sci. U.S.A. 97:11655-11660.

Schiebel, W., Pelissier, T., Riedel, L., Thalmeir, S., Schiebel, R., Kempe, D., Lottspeich, F., Sanger, H. L., and Wassenegger, M. 1998. Isolation of an RNA-directed RNA polymerase-specific cDNA clone from tomato. Plant Cell 10:2087-2101.

Schnölzer, M., Haas, B., Ramm, K., Hofmann, H., and Sänger, H. L. 1985. Correlation between structure and pathogenicity of potato spindle tuber viroid (PSTV). EMBO (Eur. Mol. Biol. Organ.) J. 4:21812190

Scofield, S. R., Tobias, C. M., Rathjen, J. P., Chang, J. H., Lavelle, D. T., Michelmore, R. W., and Staskawicz, B. J. 1996. Molecular basis of gene-for-gene specificity in bacterial speck disease of tomato. Science 274:2063-2065.

Semancik, J. S., and Conejero-Tomas, V. 1987. Viroid pathogenesis and expression of biological activity. Pages 71-126 in: Viroids and viroidlike pathogens. CRC Press, Boca Raton, FL, U.S.A.

Semancik, J. S., and Vanderwoude, W. J. 1976. Exocortis viroid: Cytopathic effects at the plasma membrane in association with pathogenic RNA. Virology 69:719-726.

Tang, X., Frederick, R. D., Zhou, J., Halterman, D. A., Jia, Y., and Martin, G. B. 1996. Initiation of plant disease resistance by physical interaction of AvrPto and Pto kinase. Science 274:2060-2063.

Thomma, B. P. H. J., Eggermont, K., Penninckx, I. A. M. A., MauchMani, B., Vogelsang, R., Cammue, B. P. A., and Broekaert, W. F. 1998. Separate jasmonate-dependent and salicylate-dependent defense-response pathways in Arabidopsis are essential for resistance to distinct microbial pathogens. Proc. Natl. Acad. Sci. U.S.A. 95:15107-15111.

Tornero, P., Conejero, V., and Vera, P. 1994. A gene encoding a novel isoform of the PR-1 protein family from tomato is induced upon viroid infection. Mol. Gen. Genet. 243:47-53.

Tornero, P., Conejero, V., and Vera, P. 1997. Identification of a new pathogen-induced member of the subtilisin-like processing protease family from plants. J. Biol. Chem. 272:14412-14419.

Vera, P., and Conejero, V. 1988. Pathogenesis-related proteins of tomato. Plant Physiol. 87:58-63.

Vera, P., and Conejero, V. 1989. The induction and accumulation of the pathogenesis-related P69 proteinase in tomato during citrus exocortis viroid infection and in response to chemical treatments. Physiol. Mol. Plant Pathol. 34:323-334.

Vera, P., and Conejero, V. 1990. Citrus exocortis viroid infection alters the in vitro pattern of protein phosphorylation of tomato leaf proteins. Mol. Plant-Microbe Interact. 3:28-32.

Wahn, K., Rosenberg-De Gomez, F., and Sänger, H. L. 1980. Cytopathic changes in leaf tissue of Gynura aurantiaca infected with the viroid of citrus exocortis disease. J. Gen. Virol. 49:355-365.

Werner, R., Muhlbach, H. P., and Guitton, M. C. 1995. Isolation of viroid-RNA-binding proteins from an expression library with nonradioactive-labeled RNA probes. Biotechniques 19:218-222.

Wightman, B., Ha, I., and Ruvkun, G. 1993. Posttranscriptional regulation of the heterochronic gene lin-14 by lin- 4 mediates temporal pattern formation in C. elegans. Cell 75:855-862.

Wolff, P., Gilz, R., Schumacher, J., and Riesner, D. 1985. Complexes of viroids with histones and other proteins. Nucleic Acids Res. 13:355-367.

Zhou, J., Tang, X., and Martin, G. B. 1997. The Pto kinase conferring resistance to tomato bacterial speck disease interacts with proteins that bind a cis-element of pathogenesis-related genes. EMBO (Eur. Mol. Biol. Organ.) J. 16:3207-3218.

\section{AUTHOR RECOMMENDED INTERNET RESOURCES}

Arabidopsis Functional Genomics Consortium: http://afgc.stanford.edu/ finkel/talk.htm

Cluster and Treeview software: http://rana.lbl.gov/EisenSoftware.htm 